Section One.

Internet, New Technologies and the Society 


\title{
Connecting Law to New Technologies: Perspectives and Challenges
}

\author{
Alexandre Cavalcanti Andrade de Araújo \\ $<$ alexandrecavalcanti.adv@hotmail.com> \\ BUENOS AIRES, Argentina
}

\section{Abstract}

Currently, countries all over the world have undergone an expressive technological transformation called digital age, in which a large part of human relations is determined by algorithms and / or artificial intelligence. The fugacity of the information age poses new challenges for the Social Sciences as a whole. Thus, Law, as a result of human rationality, will need to undergo significant transformations in order to adapt to the new social categories in metamorphosis. This article aims to discuss challenges and impacts of the postmodern technological revolution and reflect on the paradigm shifts for Law and its new directions in the digital age. It will be carried out a theoretical-critical-documentary analysis, through national and international bibliographic review, involving books, specialized periodicals, legislation and electronic sites, in order to understand the main changes in the various branches of Law. Regarding to the researched references, many speculations pointed to a situation where technology exacerbated individualism, particularism, psychological diseases, human and environmental conflicts, political division and influenced electoral processes. However, it facilitated access to information, reconfigured the relationships of time and space, optimized production processes and developed new forms of communication.

Keywords:

Digital Age; Law; Transformations; Challenges

\section{Introduction}

There is no stable product in the fluency of law. Apparently, however long-lasting a legal order is given, its evolutionary march, its perishing and 
its exhaustion is simply inevitable. With this, there is an irrepressible wave of constant transformation of society, under the tutelage of a Law that is at the same time product and process of that space, as said by the Brasilian teacher Flóscolo da Nóbrega ${ }^{1}$.

The objective that, at a certain point in human life, was merely controlling, constantly subverts its profile, in function of the social landscape, reducing the duration of human knowledge in this area to the specific conditioning of the social fact. This point of view even brings to the precise concept of Rudolph Ihering ${ }^{2}$, which sums up the question: "Law is not a pure theory, but a living force".

Up to irrefutable findings, it achieves uneasiness caused by the great Polish sociologist Zygmunt Bauman ${ }^{3}$, in his theory of liquid modernity, characterized by "a society full of confused signals, prone to change quickly and in an unpredictable way, where nothing is done to last".

Describing the dichotomous and metaphorical transition between traditional / solid society and fluid modernity, the celebrated Polish philosopher teaches:

"What all these characteristics of fluids show, in simple language, is that liquids, unlike solids, do not maintain their shape easily. Fluids, so, do not fix space or arrest time. Solids have clear spatial dimensions and neutralize impact and, therefore, reduce the significance of time (effectively resist its flow or make it irrelevant), fluids don't stick to any shape and are constantly ready (and prone) to change it; thus, for them, what counts is time more than the space that they have to occupy; space that, after all, only fill "for a moment". In a sense, solids suppress time; liquids, on the contrary, time is what matters. In describing solids, we can ignore time entirely; when describing fluids, leaving time out would be a serious mistake." 3

In this perspective, Law, as a social science, is frontally provoked to reissue its main foundations, given the impact of new technologies and the fugacity of the information age, receiving a great message of modification of the natural existential way of humanity.

1 Jose Flósculo da Nóbrega, Introdução ao Direito. 7ạ. ed. Paraíba (Sugestões Literárias 1987).

2 Lucas Bicudo, 'Robôs inteligentes podem acabar com o emprego de $40 \%$ dos advogados' (startse.com, 20 February 2017): <https:/www.startse.com/noticia/mercado/ inteligencia-artificial-automatizar-direito $>$ accessed 12 February 2020.

3 Zygmunt Bauman, Modernidade Líquida (Zahar 2001). 


\section{New Technologies - The Future of Law}

Adopting a skeptical and objective view, the information age will bring several paradigm changes, presenting benefits and harms for traditional Law. On one hand, the use of artificial intelligence (AI), robots, lawtechs / legaltechs, will come to assist Law on numerous relevant issues. However, on the other hand, totally new and unknown problems will arise, thus challenging the human / technical / professional Law capacity.

Within this perspective of uncertainty about the future of Law, a Deloitte Insight report, released in 2016, says that major reforms will take place in the legal sector over the next decade, estimating that almost $40 \%$ of jobs may end up being automated in the long term. ${ }^{4}$

Still in this panorama of paradigm changes, it is estimated that $85 \%$ of the jobs that will exist in 2030 will be new and have not yet been created, as shown by the project Designing 2030: a divided vision of the future, commissioned by Dell Technologies from the Institute For The Future $(\text { IFT })^{5}$.

Data are clear, future has already arrived. How should Law professional behave? In recent survey, Getúlio Vargas Foundation $(\mathrm{GVF})^{6}$ concluded that Law professionals will undergo a readjustment in their activities, reflecting simultaneously: (1) in the emergence of new functions that require new skills, generating completely new positions (hybrid professionals, who dominate legal specialization and familiarity with notions of programming), (2) new skills required from old roles (the requirement that lawyers start to master elementary technological vocabularies) and (3) in the new emphasis on skills and specializations that were already required to some extent and that, from the processes of technological change, acquire greater importance (the ability to work in groups and to face complex cases from interdisciplinary perspectives).

Taking into account the new skills required for Law professionals, they must also understand what challenges will be proposed for the main areas

4 Lucas Bicudo, 'Robôs inteligentes podem acabar com o emprego de $40 \%$ dos advogados’ (startse.com, 20 February 2017): <https://www.startse.com/noticia/mercado/ inteligencia-artificial-automatizar-direito $>$ accessed 12 February 2020.

5 Rafaela Carvalho, ' $85 \%$ das profissões que existirão em 2030 ainda não foram criadas' (Projetodraft.com, 8 January 2019) <https:/www.projetodraft.com/85-das-prof issoes-que-existirao-2030-ainda-nao-foram-criadas $>$ accessed 12 February 2020.

6 Fundação Getúlio Vargas, 'Futuro das profissões jurídicas - Você está preparado?' (FGV, 3 December 2018) <https://direitosp.fgv.br/sites/direitosp.fgv.br/files/arquiv os/cepi_futuro_profissoes_juridicas_quali_v5.pdf $>$ accessed 11 February 2020. 
of Law with the implementation of the digital age. Thus, through a brief example, people can have an approximate idea of the new paradigms that Law will face:

\begin{tabular}{|c|c|}
\hline Law Specialties & Paradigms related to a new technology \\
\hline Administrative Law & $\begin{array}{l}\text { Public service and police power, besides other similar state activities (such } \\
\text { as regulation, promotion, economy intervention), are directly influenced by } \\
\text { new technologies. As these administrative activities (helpful or restrictive } \\
\text { from citizen's point of view) are dependent on acts, contracts, procedures } \\
\text { and plans, all forms of inclusion of new technologies that reach these legal } \\
\text { institutions automatically generate consequences for classic administrative } \\
\text { activities that develop between public administration and citizen. The gro- } \\
\text { wing adoption, by the public authorities, of automated and digital acts, } \\
\text { electronic contracts, performance of procedures over the internet (for examp- } \\
\text { le, in bidding), digital processes and many other phenomena evidences this } \\
\text { statement.7. }\end{array}$ \\
\hline Environmental Law & $\begin{array}{l}\text { Progress, stemming from technological innovations linked to biological } \\
\text { sciences, has contributed to the discovery of many species of living beings, } \\
\text { which had not been discovered yet. As well as new elements derived from } \\
\text { fauna and flora that can provide higher expectations and longevity for } \\
\text { human being. However, linked to this progress, other concerns related to } \\
\text { human life arises. And the most important of all are: the right to life and the } \\
\text { environmental preservation. Through this logic, the controversial discussion } \\
\text { about the existence of effective protection, as well as the sustainable use of } \\
\text { natural resources arises. }\end{array}$ \\
\hline Banking Law & $\begin{array}{l}\text { The topics related to blockchain, cryptocurrencies and smart contracts cause } \\
\text { many questions, doubts and, of course, a lot of curiosity in the legal environ- } \\
\text { ment. So, there are some main challenges: } \\
\text { Difficulty in reaching the concept - The theme is complex and involves } \\
\text { a series of new concepts and practices, so keeping yourself well-informed is } \\
\text { important, above all, to follow the details of this subject. } \\
\text { Immunity to censorship - Regulate and limitate bitcoin mining, for examp- } \\
\text { le, are requirements that may not be effective in today's reality. } \\
\text { Poor flow control across borders - It is being even more difficult to have } \\
\text { a sistematic control due to the fact that the resources circulate without } \\
\text { state control.9 }\end{array}$ \\
\hline
\end{tabular}

7 Thiago Marrara, 'Direito Administrativo e Novas Tecnologias' (Genjurídico.com, 19 December 2017) <http://genjuridico.com.br/2017/12/19/direito-administrativo-n ovas-tecnologias $>$ accessed 18 February 2020.

8 David Silva de Souza and and Daiane Acosta Amaral, 'Meio ambiente, sociedade e tecnologia' (Ambitojuridicio.com, 1 July 2014) <https://ambitojuridico.com.br /cadernos/direito-ambiental/meio-ambiente-sociedade-e-tecnologia $>$ accessed 18 February, 2020.

9 Rosine Kadamani, 'Blockchain e os efeitos das novas tecnologias no Direito' (blockchainacademy.com.br, 21 November 2018) <https://blockchainacademy.c om.br/blockchain-e-os-efeitos-das-novas-tecnologias-no-direito-especial-aurumsum mit2018> accessed 29 May 2020. 


\begin{tabular}{|c|c|}
\hline Law Specialties & Paradigms related to a new technology \\
\hline Consumer Law & $\begin{array}{l}\text { Companies are everywhere (in your home and in your neighborhood, your } \\
\text { state, city, country), through the internet (social and commercial sites, such } \\
\text { as facebook, twitter, instagram, virtual stores, submarine, free market, among } \\
\text { others), causing direct and indirect autonomy control, when related to their } \\
\text { freedom of choice. Due to the presence of these organizations is detected } \\
\text { a high degree of competition, sending their products everywhere, without } \\
\text { barriers, adopting universal strategies that meet the consumers interests. The } \\
\text { State Power is silent in relation to this invasion, due to the fact that it } \\
\text { benefits yourself with your own omission. }{ }^{10}\end{array}$ \\
\hline Contract Law & $\begin{array}{l}\text { The use of new technologies and the emergence of the 'stuff internet', made } \\
\text { inter-system contractual relations grow, where machines manifests the ability } \\
\text { to employ above others causing obligations between them and telematic } \\
\text { contracts have evolved into a new concept, called digital contracts. } \\
\text { The evolution of form was also accompanied by the transformation of the } \\
\text { willingness manifestation. Even as the hirer and the hired will be represented } \\
\text { by machines, the registration of this hiring, even if it is made by a human } \\
\text { act, it will also be done by a machine, with the advantage of increase the } \\
\text { legal security of the relationship through greater proof of authenticity (proof } \\
\text { of authorship). } \\
\text { In other words, what long clauses provide for indemnity, responsibilities, } \\
\text { declarations, guarantees, escrow account, are used for? }{ }^{11}\end{array}$ \\
\hline Philosophy of Law & $\begin{array}{l}\text { It offers knowledge of logic, philosophy of mathematics, theory of know- } \\
\text { ledge, anthropology, rhetoric, argumentation, writing, as well as the ability } \\
\text { to face problems and complex texts. } \\
\text { It favors the abstract reasoning that allows to analyze the complex informati- } \\
\text { on that is received in a speech and, at the same time, integrate a lot of data in } \\
\text { fragmented ways, from different sources of knowledge branches. } \\
\text { It fosters a critical spirit and the habit of thinking by your ownself deeply, } \\
\text { characterized by the ability to ask the right questions in face of new situati- } \\
\text { ons. } \\
\text { Educates aiming to the hability to dialogue, which implies create an awaren- } \\
\text { ess that it is just a point of view. In this way, it is possible to achieve openness } \\
\text { to news and your personal examination. } \\
\text { It generates a special ethical sensitivity, gained through knowledge and } \\
\text { reflection of the various ethical proposals that philosophers have offered } \\
\text { throughout history. }\end{array}$ \\
\hline
\end{tabular}

10 Jeane Nascimento, 'As relações de consumo frente os avanços tecnológicos versus a globalização e manipulação no direito de escolha do consumidor' (Jusbrasil, 2015 ) <https://jeanecnascimento.jusbrasil.com.br/artigos/195135894/as-relacoes-d e-consumo-frente-os-avancos-tecnologicos-versus-a-globalizacao-e-manipulacao-no -direito-de-escolha-do-consumidor> accessed 29 May 2020.

11 Por Patricia Peck Pinheiro, 'Contratos digitais: apenas um meio ou nova modalidade contratual?’ (Conjur.com.br, 29 July 2016) <https://www.conjur.com.br/20 16-jul-29/patricia-peck-contratos-digitais-sao-modalidade-contratual $>$ accessed 4 March 2020. 


\begin{tabular}{|c|c|}
\hline Law Specialties & Paradigms related to a new technology \\
\hline Philosophy of Law & $\begin{array}{l}\text { Philosophers have the role of making a slowly, rigorous and integrating } \\
\text { reflection on the consequences for the human life of the scientific and tech- } \\
\text { nological changes that we are experiencing. }{ }^{12}\end{array}$ \\
\hline International Law & $\begin{array}{l}\text { Modernization implied an increase in risk, for the individual and for the } \\
\text { state. If at the beginning of industrialization the risk was personal or local, it } \\
\text { is now impersonal and global. } \\
\text { At the same time that modern society has a great technical and scientific } \\
\text { knowledge, it is not free from the impact of multiple risks, as social, political } \\
\text { and environmental (like the urban riots in Paris in } 2005 \text {, that quickly spread } \\
\text { to neighboring countries; like the contamination of water in international ri- } \\
\text { vers; as the war between states and refugee immigrants, acid rain, the import } \\
\text { of transgenic food, etc.). These are risks that know neither the borders nor } \\
\text { the limits of the state legal systems. }\end{array}$ \\
\hline Criminal Law & $\begin{array}{l}\text { With the increase in illicit practices through new information and communi- } \\
\text { cation technologies, social peace is undermined, with such illegal conduct } \\
\text { being linked to financial fraud, apology to crime, violation of privacy, child } \\
\text { pornography, among others. And Criminal Law, in face of new behaviors } \\
\text { practiced on web or through these new technologies, cannot ignore and } \\
\text { need to face the issue proposed. There is an influence on criminal and } \\
\text { procedural rules showing that they are outdated, fragile or ineffective in face } \\
\text { of new conduct that violates web rights, requiring updates. }{ }^{14}\end{array}$ \\
\hline Civil Procedural Law & $\begin{array}{l}\text { Online dispute resolution platforms; jurimetrics that is the application of } \\
\text { quantitative methods, usually statistics, to law, using a quantitative approach } \\
\text { to analyze judicial decisions; the use of robots, decisions by algorithm, virtu- } \\
\text { al plenary, online arbitration. In summarize, there are many thought-provo- } \\
\text { king questions that challenge legal operators, notably proceduralists. }{ }^{15}\end{array}$ \\
\hline Civil Responsability & $\begin{array}{l}\text { Control technological development and its social and economic reflexes is } \\
\text { certainly one of the most challenging missions attributed to Law. One of the } \\
\text { main aspects of this challenge is to approach the development risks. These } \\
\text { risks are imprecise and uncertain and they can be explained into a simple } \\
\text { question: if the product or service had a problem that was undetectable by } \\
\text { the scientific and technical knowledge at that time, the supplier must answer } \\
\text { for damages resulting from something that did not exist at that time? }\end{array}$ \\
\hline
\end{tabular}

12 Universia Brasil, 'Por que é importante a Filosofia na Era Digital?' (Universia.net/br, 19 Decemebr 2018) <https://noticias.universia.com.br/destaque/not icia/2018/12/26/1163322/importante-filosofia-digital.htm> accessed 9 March 2020.

13 Nuno Vieira de Carvalho, 'O direito internacional na era da globalização e do risco' (www.criticanarede.com, 2 April 2006) <https://www.mpam.mp.br/centros -de-apoio-sp-947110907/combate-ao-crime-organizado/doutrina/492-o-direito-inter nacional-na-era-da-globalizacao-e-do-risco $>$ accessed 27 May 2020.

14 Dayane Fanti Tangerino, 'Direito penal e novas tecnologias'(Jusbrasil, 2015) $<$ https://canalcienciascriminais.jusbrasil.com.br/artigos/293902178/direito-pe nal-e-novas-tecnologias> accessed 28 May 2020.

15 Darci G. Ribeiro, 'Processo e novas tecnologias: desafios e perspectivas' (www.mig alhas.com.br, 6 December 2019) <https://www.migalhas.com.br/depeso/316523/p rocesso-e-novas-tecnologias-desafios-e-perspectiva> accessed 28 May 2020.

16 Guilhereme Henriquie Lima Reinig And Daniel A. Carnaúba,, 'Responsabilidade civil e novas tecnologias: riscos do desenvolvimento retornam à pauta' (www.conj 


\begin{tabular}{|l|l|}
\hline \multicolumn{1}{|c|}{ Law Specialties } & \multicolumn{1}{|c|}{ Paradigms related to a new technology } \\
\hline Labor Law & $\begin{array}{l}\text { There was a change of paradigms in the ways of work relationship, and with } \\
\text { automated and restructured production, another kind of worker came into } \\
\text { existence. A tough battle is going on, with globalization being placed as an } \\
\text { affront to Labor Law by eliminating employment through automation and } \\
\text { the división of labor process around the world. There is a great demand on } \\
\text { searching for qualified labor to adjust to the new flexibility requirement. In } \\
\text { addition, sophistication in service is sought, the existence of an infrastructure } \\
\text { in services to support the maintenance process of companies and globalizati- } \\
\text { on. }{ }^{17}\end{array}$ \\
\hline Tributary Law & $\begin{array}{l}\text { The digital economy implies challenges and perplexities that have not been } \\
\text { articulated yet. It changes the way we communicate, consume and work. } \\
\text { New businesses and types of commerce appears. Increases capital flow. Intan- } \\
\text { gible assets are growing in importance. The tributary system must also chan- } \\
\text { ge: adapt to challenges imposed by the digital revolution. There is growing } \\
\text { evidence that many of the current taxes will soon become obsolete, given } \\
\text { the dynamism of electronic commerce and new economy. Income, consump- } \\
\text { tion and employment were deeply affected by new values, current forms of } \\
\text { business and work. The three pillars of } 20^{\text {th }} \text { century assessment had been } \\
\text { shaken by the ongoing digital revolution. Although there is much literature } \\
\text { and discussion on how structural changes will affect each macroeconomic } \\
\text { variables and even how to modernize tributary collection, the discussion } \\
\text { about the necessary changes in tributary systems remains incipient. It will } \\
\text { not be necessary to change just practices. It is also important to rethinking } \\
\text { about fiscal policy and, above all, the current configuration of tributary } \\
\text { powers. }{ }^{18}\end{array}$ \\
\hline
\end{tabular}

As it turns out, the legal sciences are directly challenged to reflect and rethink their main fundamentals, since they are impacted by new technologies, without leaving apart the great role of Law to prescribe, at the same time, parameters and rules, limiting the unrestrained cyber character and giving protection and pacific cohexistance by the subjects.

On this situation, the teacher Maria Helena Diniz ${ }^{19}$ in her Introduction to the Science of Law Compendium, exposes a feature of the systemicity of Law:

ur.com.br, 25 November 2019) <https:/www.conjur.com.br/2019-nov-25/direito-c ivil-atual-riscos-novas-tecnologias-retornam-pauta\#author> accessed 29 May 2020.

17 Lourival J. de Oliveira, 'Os princípios do direito do trabalho frente ao avanço tecnológico’ (www.ambitojuridico.com.br, 20 April 2008) <https://ambitojuridico .com.br/edicoes/revista-52/os-principios-do-direito-do-trabalho-frente-ao-avanco-te cnologico $>$ accessed 30 April 2020.

18 Celso B. C. Neto, José R. R. Alfonso and Luciano F. Fuck 'A tributação na era digital e os desafios do sistema tributário no Brasil' (2019) Revista 15, 1 Brasileira de Direito <https://seer.imed.edu.br/index.php/revistadedireito/article/view/3356/ 2344> accessed 19 February1 2020.

19 Maria H. Dinz, Compêndio de introdução à ciência do direito (Editora Saraiva 2012). 
"Scientific knowledge - says the author - is not knowledge that is ready and finished. It is, rather, knowledge obtained and elaborated deliberately, with an awareness of the purposes proposed by the means to carry it out, aiming at its justification as true and certain knowledge." 19

Thus, the previously reflexive attitude about the impacts of changes in the paradigms in Law, imposes a deep concern on how to achieve to merge or systematize the information age and the new directions of the Legal Sciences, taking into account the re-significance of the human condition and the new forms of transhuman sociability.

\section{Conclusion}

Given the situation presented, many speculations point to a scenario where technology exacerbated individualism, particularism, psychological diseases, human and environmental conflicts, political division and influenced electoral processes. However, it facilitated access to information, reconfigured the relationships of time and space, optimized production processes and developed new forms of communication.

In this perspective, the operator of postmodern Law will need a proficient qualification, because new technological skills will be demanded. However, as Giorgio Del Vecchio ${ }^{20}$ points out: "a simple temporal association made to achieve some particular objective, but also a necessary communion, directed towards the perfection of life".

What is needed today, are not law operators who know the laws, or write a good contract, or know the jurisprudence. This, machines are already doing and will do even better! What is needed is lawyers who understand technology, operate their machines and, mainly, do what machines do not know how to do: understand the human being and relate better to each other.

20 Giorgio del Vecchio, Filosofia Del Derecho (Bosh Casa Editorial S.A. 1929). 